\title{
EFFECT OF DIETARY PHOSPHORUS ON PROTEIN INTAKE AND PRODUCTIVE PROTEIN VALUE OF YOUNG HYBRID AFRICAN CATFISH (PISCES: CLARIIDAE)
}

\author{
Ugwu, L.L.C. ${ }^{1}$, Mgbenka, B.O. ${ }^{2}$ and Asogwa, M.O. ${ }^{1}$
}

\begin{abstract}
Three hundred and sixty four weeks old advanced fry of the hybrid African catfish (Clarias gariepinus () $x$ H. Heterobranchus bidorsalis (ठ))) (mean weight, $1.25 \pm 0.02$ g) were obtained from the hatchery of the African Regional Aquaculture Centre (ARAC), Port Harcourt, Nigeria and held in 15 aerator-fitted glass tanks $\left(55 \times 30 \times 30 \mathrm{~cm}^{3}\right)$ at the Research Laboratory of the Ebonyi State University, Abakaliki, Nigeria. Batches of 20 fry were introduced into the flooded glass tanks and fed compounded diets for 35 days at 4-hourly intervals daily from 0800 - 2000 hours and fed 3 times daily thereafter for a total of 42 days at $5 \%$ body weight per day $\left(b w d^{-1}\right)$. The diets were compounded isonitrogenous at $38 \%$ crude protein (CP) with 4 inclusion levels $(0.60,0.80,1.00,1.20 \%)$ of phosphorus $(P)$ applied as monocalcium phosphate $\left\{\mathrm{Ca}_{3}\left(\mathrm{PO}_{4}\right)_{2}\right\}$. The inclusion levels of the conventional feed ingredients (yellow maize, soyabean meal, blood meal and rice bran) were staggered in accordance with their protein and $P$ contents and in order to achieve the desired dietary $P$ levels. The average weekly feed intake (FFW), protein intake (PI), feed conversion ratio (FCR) and proximate composition of fish and diets were determined. Also, productive protein value (PPV), the ratio of retained body protein-to-protein intake was determined. The average weekly feed intake increased with dietary $P$ increase for 0.60 (1.46 g), 0.80 $(1.57 \mathrm{~g}), 1.20(1.80 \mathrm{~g})$ and not for $1.00 \%$ (1.44 g). This increasing response trend was demonstrated in the FCR and PPV of fish where the 1.00\% dietary P had the best fish response and the $1.20 \%$ dietary $P$ had the least response. This result also paralleled the least values of protein and fat depositions recorded for $1.20 \%$ dietary $P$ level whereas the other dietary $P$ levels and the control were comparatively higher. It was evident that the experimental fish probably demonstrated a consistent response to increasing dietary $P$ level between 0.60 and $0.80 \%$ P for FFW, FCR, PPV and PI, and the values obtained were respectively lower than the value for control. There was depression in protein deposition between $0.60 \% \mathrm{P}(19.25 \%)$ and $0.80 \% \mathrm{P}$ of (18.94\%) while fish fed the control diet deposited more quantity of protein (19.63\%). Conversely, there was an enhanced fat deposition as the dietary $P$ increased from 0.60 to $0.80 \%$ while the control diet paralleled that of $0.60 \% P$. However, the mean lipid content of fish decreased with increasing $P$ level. Generally, there was no significant effect $(P>0.05)$ of increasing the dietary $P$ level on the response of fish to $F F W, F C R$, PI and PPV.
\end{abstract}

Key words: Catfish hybrid, dietary phosphorus level, protein intake, productive protein value, protein deposition.

\section{INTRODUCTION}

Phosphorus (P), required for normal growth in fish is the third most expensive nutrient following energy and protein (Potchanakorn and Potter, 1987). It is considered the most limiting nutrient for plant and algal growth in freshwater estuaries (Dobbins and Boyd, 1976). Natural feed ingredients of animal origin have high levels of $P$ (Reintz et al., 1978). As a result, it is cost effective to use feed ingredient of plant origin, supplemented with inorganic $\mathrm{P}$, to achieve optimum dietary $\mathrm{P}$ for growth and survival in fish (Cho \& Bureau 2001).

Various studies carried out by fish nutritionists on dietary $\mathrm{P}$ uptake of various fish 
species indicated that the channel catfish (Ictalurus punctatus) fingerlings, raised under laboratory conditions and fed semi-purified diets containing graded levels of $\mathrm{P}$, required from $0.33 \%$ (Wilson et al., 1982) to 0.40 (Lovell, 1978) available P for maximum growth. Hence, commercial catfish feeds have been formulated to contain $0.4-0.5 \%$ available P. When animal protein such as fishmeal was used as a feed component, the high level of $\mathrm{P}$ in the animal protein resulted in excessive $\mathrm{P}$ content in commercial feeds. Therefore, the application of such feeds in aquaculture systems resulted in the release of large amounts of $\mathrm{P}$ in the water, thus increasing the P loads of effluents (Kendra, 1991) or in the sediments surrounding cage culture systems (Kelly, 1993).

Ways to reduce $\mathrm{P}$ loads in effluents made researchers evaluate such procedures as: sieving the effluents before releasing to the environment (Makinen et al., 1988); supplementing diets with more insoluble P sources (Ketola and Harlard, 1993); or collecting and pumping wastes out of settling areas (Behmer et al., 1993). Probably, the most effective way to minimize phosphorus discharge to the environment is to reduce the amount of dietary $P$ to a level as low as possible while still maintaining optimal fish health and performance by inclusion of $\mathrm{P}$ supplied from plant ingredients which are relatively low in available $\mathrm{P}$ and supplementing with inorganic P sources (NRC, 1993).

This study investigated the effect of dietary phosphorus on protein intake and productive protein value defined by increase of body protein $(\%) /$ protein intake $(\%)$ (Faturoti et al., 1986) of young hybrid African catfish (Clarias gariepinus (q) x Heterobranchus bidorsalis $(\widehat{\circlearrowleft})$ ). Criteria for evaluation were feed intake, protein intake, productive protein value and proximate composition of fish and diets.

\section{METHODOLOGY \\ Experimental procedure}

Three hundred and sixty four weeks old advanced fry of the Hybrid African catfish (C. gariepinus $\mathrm{x}$ H. bidorsalis) (mean weight, $1.25 \pm 0.02 \mathrm{~g}$ ) were obtained from the hatchery of the African Regional Aquaculture Centre (ARAC), Aluu, Port-Harcourt, Nigeria and held in 15 aerator-fitted glass tanks $\left(55 \times 30 \times 30 \mathrm{~cm}^{3}\right)$ at the Research Laboratory of Ebonyi State University, Abakaliki, Nigeria. The temperature range throughout the experimental period was between $24^{\circ} \mathrm{C}$ and $28^{\circ} \mathrm{C}$ while the water $\mathrm{pH} 6.80$. Batches of 20 fry were introduced into the tanks and fed compounded diets at four-hourly intervals starting from 08.00 hours daily. Diet components (Table 1) were milled and mixed, pelleted with locally fabricated pelletizer, sun-dried and packaged in polythene bags, labeled according to dietary treatments and stored in a pest-free cupboard.

The diets were compounded isonitrogenous at $38 \%$ crude protein with four inclusion levels $(0.60 \%, 0.80 \%, 1.00 \%, 1.20 \%)$ of $\mathrm{P}$ applied as monocalcium phosphate $\left\{\mathrm{Ca}_{3}\left(\mathrm{PO}_{4}\right)_{2}\right\}$. The inclusion levels of the conventional feed ingredients (yellow maize, soyabean meal, blood meal and rice brain) were staggered in accordance with their protein sources and $\mathrm{P}$ contents, and in order to achieve the desired dietary P levels (Table 1). The fish were fed for 35 days at 4-hourly intervals daily from $0800-2000$ hours and fed 3 times daily thereafter for a total of 42 days at $5 \%$ body weight per day $\left(\mathrm{bw} \mathrm{d}^{-1}\right)$.

Sample weighing with the aid of a Mettle balance was carried out every 7 days and feed allowance adjusted in accordance with the body weight of fish. The filtration system in fish tanks aided in the collection of faeces and other residues. Temperature readings of water in each tank were taken at the commencement of feeding with the aid of a Celsius mercuryin-glass thermometer, while the water $\mathrm{pH}$ was recorded with the aid of a $\mathrm{pH}$ meter. At the beginning of the experiment and after the weekly sample weighing, some fry were sacrificed and their carcass oven-dried and preserved for analysis. 


\section{Method of Analyses}

Proximate compositions of fish and diets

The proximate compositions of diets (Table 2) and fish (Table 3) were carried out using A.O.A.C. (1990) method at the beginning and end of the experiment. The nitrogen content was determined by the microkjeldahl technique. Crude fat was measured in a soxhlet apparatus of lipid by petroleum ether (b. pt. $40-60^{\circ} \mathrm{C}$ ) extraction, the dry weight was determined by drying at $105^{\circ} \mathrm{C}$ for 24 hours and ashed by combusting in a muffle furnace at $550^{\circ} \mathrm{C}$ for 12 hours. The crude fiber was determined by the asbestos method. The nitrogen free extract (NFE) was determined as the difference between the ash, moisture, protein and fat contents, crude fiber and a hundred (100).

\section{Determinations of $\mathrm{Ca}$ and $\mathrm{P}$ in fish and diets}

Samples of fish or diets were wet-ashed, first with $\mathrm{HNO}_{3}$ then followed by $\mathrm{HClO}_{4}$ (Johnson and Ulrich, 1959). Ca was then determined with atomic absorption spectrophotometer (SP 1900 Pye Unicon) at $422.4 \mathrm{~nm}$ using a stoichiometric $\mathrm{C}_{2} \mathrm{H}_{2}-\mathrm{N}_{2} \mathrm{O}$ flame. Phosphorus was determined calorimetrically (John 1970) at $827 \mathrm{~nm}$ in a Shimdzu UV -240 spectrophotometer.

\section{Estimation of growth parameters}

The productive protein value, a ratio of retained body protein-to-protein intake was determined as in Faturoti et al. (1986); while the protein intake was estimated as feed intake/percentage protein in the diet. Feed conversion ratio (FCR) was the relationship of the feed intake $(\mathrm{g})$ /mean weight gain $(\mathrm{g})$.

\section{Statistical analysis}

All the data obtained were subjected to statistical analysis by Steel and Torrie (1980). Any significant difference was partitioned with Fisher's least significant difference (F-LSD) and the Duncan's Multiple Range Test.

\section{RESULTS}

The average weekly feed intake (FFW) of the experimental fish is shown in Table 4. FFW estimates showed a corresponding though non-significantly different $(\mathrm{P}>0.05)$ increase with increasing dietary $\mathrm{P}$ levels $(0.6,0.80$ and $1.20 \%$ i.e. $1.46,1.57$ and $1.84 \mathrm{~g})$ respectively but not with $1.00 \% \mathrm{P}$ level (1.12), which showed a depressed response relative to the $0.80 \% \mathrm{P}$ level (Table 4). Similar trend was demonstrated in the feed conversion ratio (FCR). For the productive protein value (PPV), the $1.00 \%$ dietary $\mathrm{P}$ had the best fish response and the $1.20 \%$ $\mathrm{P}$ had the least response. This result paralleled the least values of protein and fat depositions recorded for the $1.20 \%$ dietary $\mathrm{P}$ level (Table 3 ) whereas the other dietary P levels and the control were comparatively higher.

In all, it was evident that the fish probably demonstrated consistent but nonsignificantly different $(\mathrm{P}>0.05)$ response to increasing dietary $\mathrm{P}$ level between 0.60 and $0.80 \%$ P supplementation for FFW, FCR, PI and PPV and the values obtained were lower than the control. Irrespective of the response to these parameters, there was a depression in protein deposition between $0.60 \% \mathrm{P}(19.25)$ and $0.80 \% \mathrm{P}(18.94)$ while fish fed the control diet deposited more quantity of protein (19.63) (Table 3). Conversely, there was an enhanced fat deposition as the dietary $\mathrm{P}$ increased from $0.60(1.63)$ to $0.80 \%(1.80)$ while the control diet (1.64) paralleled that of $0.60 \%$ dietary P. Table 4 also showed that the average ash content of fish decreased from 3.31 to $3.15 \%$ as the dietary P increased from 0.60 to $1.20 \%$ (Table 3). Generally, there was no significant effect $(\mathrm{P}>0.05)$ of increasing the dietary $\mathrm{P}$ level in response of fish to FFW, FCR, PI and PPV respectively.

The dietary P level-period (days) interaction of fish showed that there was no defined 
increase or decrease in FCR over time. However, there were definite accelerated responses of fish to the above parameter within the first 7 days of the experiment (Tables 5). It was also evident that the fish ability to convert ingested food to body tissue (FCR) was generally depressed from day 21 to day 35 for all the dietary P levels while the best FCR was recorded on day 14 (Table 5).

\section{DISCUSSION}

The apparent increase in the average weekly feed intake with increasing level of dietary $\mathrm{P}$ was in accordance with the day to day variation in feed intake for fishes as reported by earlier workers (De Silva and Parera, 1976). Since the diets used in this study were compounded isonitrogenous at $38 \% \mathrm{CP}$, it was presumed that the protein intake (PI), expressed as the relationship between the weekly feed intake and percentage protein in the diet, would be reflective of the quantity of feed taken. This presumption was corroborated by the consistent responses of fish to FFW and PI respectively as the dietary P level increased from 0.60 to $0.80 \%$ (Table 4 ). The equitable productive protein values $(0.60)$ recorded for 0.60 and $0.80 \%$ dietary $\mathrm{P}$ suggested that despite the better though not significantly different $(\mathrm{P}>0.05)$ feed and protein intake (Table 4$)$ from 0.60 to $1.20 \%$ dietary $\mathrm{P}$ fish fed between 0.60 and $0.80 \%$ dietary $\mathrm{P}$ apparently deposited the good productive protein necessary for body growth. The result of this study agrees with the NRC (1983) report that most warm water fishes require between 0.33 and $0.80 \%$ dietary $\mathrm{P}$ for maximum growth.

The least lipid content of fish recorded with the highest dietary P level $(1.20 \%)$ recorded in this study was in consonance with the report of Eya and Lovell (1997) for channel catfish (Ictalurus punctatus). They recorded decreases in lipid content of the muscle, liver and vertebra as the dietary P levels increased. It was then thought that the reason for this development could be due to the enhancement of $\beta$-oxidation of fatty acids, glycogenesis or some repartitioning effect resulting in decreased fat deposition and those physiological processes in the fish resulted in increased protein deposition. This study recorded a nonsignificantly different decrease in protein deposition at the higher P level (1.20\%) which may indicate that possibly the concept of increasing the dietary $\mathrm{P}$ level of the diets of the young hybrid African catfish beyond an optimum $\mathrm{P}$ requirement $(0.60$ to $0.80 \% \mathrm{P})$ could retard nitrogen retention and by extension the productive protein value and protein accretion as suggested by Eya and Lovell (1997) for channel catfish. This agrees with Coloso et al. (2003) findings that although increasing concentration of available $\mathrm{P}$ from $0.24 \%$ to $0.88 \%$ modestly enhanced growth in the rainbow trout (Oncorhynchus mykiss), beyond $0.88 \%$ available $\mathrm{P}$ growth of the fish did not improve.

\section{REFERENCES}

A.O.A.C. (Association of Official Analytical Chemists) 1990. Official Methods of Analysis. 15 edn. Arlington, V.A. 1298 pp.

Behmer, D., Griel, R.W., Griel, D.C. and Fessel, B.P. 1993. Evaluation of conebottom cages for the removal of solid wastes and phosphorus from pen-cultured rainbow trout. Progressive Fish-culturist. 55: 255 - 260.

Cho C. Y. and Bureau D. P. 2001. A review of diet formulation strategies and feed systems to reduce excretory and feed wastes in aquaculture. Aquaculture 32(1-4): 349.

Coloso R. M, King K., Fletcher J. W., Hendrix M. A., Subramanyam M., Weis P. and Ferraris R. P. 2003. Phosphorus utilization in rainbow trout (Oncorhynchus mykiss) fed practical diets and its consequences on effluent phosphorus levels. Aquaculture 220 (1-4): $801-820$.

Dobins, D.A. and Boyd, C.E. 1976. Phosphorus and potassium fertilization of sunfish ponds. Trans. Am. Fish. Soc. 105: 536 - 540. 
De Silva, S.S. and Parera, P.A.B. 1976. Studies on the young gray mullet, Mugil cephalus L Effects of salinity on food intake, growth and food conversion. Aquaculture, 7: 327-338.

Eya, J.C. and Lovell, R.T. 1997. Available phosphorus requirement of food-size channel catfish (Ictalurus punctatus) fed practical diets in ponds. Aquaculture, 154: 283 291.

Faturoti E.O., A.M. Balogun and L.L.C. Ugwu. 1986. Nutrient utilization and growth responses of Africa catfish (Clarias lazera) fry fed different dietary protein levels. Nigerian Journal of Applied Fisheries and Hydrobiology. 1: 41-45.

John, M.K., 1970. Calorimeter determination of phosphorus in soil and plant materials with ascorbic acid. Soil Science, 109: $214-220$.

Johnson, C.M. and Ulrich, A. 1959. Analytical methods for use in plant analysis. California Agricultural Experimental Station Bulletin. No. 766: 25 - 78. California: University of California.

Kendra, W. 1991. Quality of salmon hatchery effluents during summer low-flow season. Transactions of American Fisheries Society, $120: 43$ - 51.

Kelly, L.A. 1993. Release rate and biological availability of phosphorus released from sediments receiving aquaculture wastes. Hydrobiologia, 253: $367-372$.

Ketola, H.G. and Harland, B.F. 1993. Influence of phosphorus in rainbow trout diets in phosphorus discharges in effluent water. Trans. Am. Fish. Soc. 122: $1120-1126$.

Lovell, R.T. 1978. Dietary phosphorus requirement of channel catfish (Ictalurus punctatus). Trans. Am. Fish. Soc., 107: 617 - 621.

Makinen, T., Lindgren, S. and Eskalinen, P. 1988. Sieving as an effluent treatment method of aquaculture. Aquaculture Engineering 17: 367-377.

NRC (National Research Council). 1983. National requirement of warm water fishes. National Academy of science, Washington, D.C., U.S.A.

NRC (National Research Council). 1993. Nutrient requirement of fish. Nutrient requirement of domestic animals. National Academy Press, Washington, D.C., DLSA.

Potchanakorn, M. and Potter, L.M. 1987. Biological values of phosphorus from various sources for young turkey Poultry Science 66: 505-513.

Reinitz, G.L., Orma, L.E., Lamn, C.A. and Hitzel, F.N. 1978. Influence of varying lipid concentration with two-protein concentration in diet for rainbow trout (Salmo gairdneri). Trans. Am. Fish. Soc. 107(5): 751-754.

Steel, R.G.D. and Torrie, J.H. 1980. Principles and procedures of statistics: with special reference to biological sciences. Mc Graw-Hill, New York, NY. 481pp.

Wilson, R.P., Robinson, E.H., Gatlin III, D.M. and Poe, W.E. 1982. Dietary phosphorus requirement of channel catfish. J. Nutr. 112: $1197-1202$. 
Table 1: Gross and proximate composition of experimental diets fed to young hybrid African catfish (Pisces: Clariidae) for 42 days.

\begin{tabular}{llllll}
\hline \multirow{2}{*}{ Feed ingredient } & \multicolumn{6}{l}{ Diet, Phosphorus $(\mathrm{P})$ level (\%) } \\
\cline { 2 - 6 } & $\mathrm{D}_{1}, 0.60$ & $\mathrm{D}_{2}, 0.80$ & $\mathrm{D}_{3}, 1.00$ & $\mathrm{D}_{4}, 1.20$ & $\mathrm{D}_{5}$, Control \\
\hline Yellow maize & 14.15 & 14.01 & 50.79 & - & 16.66 \\
Soyabean meal & 73.77 & 73.65 & - & - & 42.33 \\
Rice bran & - & - & - & 53.33 & 15.15 \\
Blood meal & - & - & 36.75 & 34.05 & 14.11 \\
Bone meal & 2.50 & 2.50 & 2.50 & 2.50 & 2.50 \\
Palm oil & 5.00 & 5.00 & 5.00 & 5.00 & 5.00 \\
AD. Vit & 4.00 & 4.00 & 4.00 & 4.00 & 4.00 \\
Salt $(\mathrm{NaCl})$ & 0.25 & 0.25 & 0.25 & 0.25 & 0.25 \\
Calcium phosphate & 0.33 & 0.53 & 0.71 & 0.87 & 0.00 \\
Total & 100.00 & 100.00 & 100.00 & 100.00 & 100.00
\end{tabular}

${ }^{1}$ AD. Vit: A Pfizer livestock feeds production supplying the following vitamins and minerals per gram of diet: A, 9823 I.U; $\mathrm{D}_{3}, 1965$ I.U.; B 12,10 g/ton; Riboflavin, 10mg; Manganese, 341mg; Copper, 244mg; Zinc, $100 \mathrm{mg}$; Iodine, $20 \mathrm{mg}$; and Oxytetracyline hydrochloride, 20 $\mathrm{mg} / \mathrm{ton}$.

Table 2. Mean values of analyzed nutrients of the different experimental diets fed to young hybrid African catfish (Pisces: Clariidae) for 42 days.

\begin{tabular}{llllll}
\hline Nutrient variables & \multicolumn{5}{l}{ Diet, Phosphorus (P) level (\%) } \\
\cline { 2 - 6 } & $\mathrm{D}_{1}, 0.60$ & $\mathrm{D}_{2}, 0.80$ & $\mathrm{D}_{3}, 1.00$ & $\mathrm{D}_{4}, 1.20$ & $\mathrm{D}_{5}$, Control \\
Ether extract & 4.64 & 5.02 & 4.85 & 4.72 & 4.64 \\
Moisture content & 11.70 & 11.61 & 11.68 & 11.65 & 11.60 \\
Ash & 10.56 & 10.65 & 10.58 & 10.56 & 10.55 \\
$\begin{array}{l}\text { Nitrogen free extract } \\
\text { (digestible carbohydrate) }\end{array}$ & 34.22 & 34.83 & 35.67 & 36.21 & 35.85 \\
\hline
\end{tabular}

Table 3: Proximate composition of the hybrid African catfish (Clarias gariepinus $x$ Heterobranchus bidorsalis) after 42 days of feeding graded levels of dietary phosphorus

\begin{tabular}{|c|c|c|c|c|c|c|}
\hline \multirow[b]{2}{*}{ Nutrient variable $(\%)$} & \multicolumn{6}{|c|}{ Diet, Supplemented phosphorus (P) levels in diet (\%) } \\
\hline & $\begin{array}{l}\text { D1, } \\
0.60\end{array}$ & $\begin{array}{l}\mathrm{D} 2, \\
0.80\end{array}$ & $\begin{array}{l}\text { D3, } \\
1.00\end{array}$ & $\begin{array}{l}\mathrm{D} 4, \\
1.20\end{array}$ & $\begin{array}{l}\text { D5 (Control), } \\
0.00\end{array}$ & $\begin{array}{l}\text { Initial } \\
\text { fish }\end{array}$ \\
\hline Crude protein & 19.25 & 18.94 & 19.17 & 18.73 & 19.63 & 19.30 \\
\hline Ether extract & 1.63 & 1.80 & 1.67 & 1.55 & 1.64 & 1.72 \\
\hline Moisture content & 71.60 & 70.20 & 70.60 & 70.90 & 70.95 & 70.56 \\
\hline Ash & 3.31 & 3.23 & 3.16 & 3.15 & 3.19 & 3.64 \\
\hline Nitrogen free extract & 4.21 & 5.83 & 5.40 & 5.67 & 4.59 & 4.78 \\
\hline Total & 100.00 & 100.00 & 100.00 & 100.00 & 100.00 & 100.00 \\
\hline Phosphorus contents & 0.05 & 0.06 & 0.07 & 0.07 & 0.14 & 0.08 \\
\hline
\end{tabular}


Table 4: Mean values ( \pm standard error of mean) of feed intake, feed conversion, protein intake and productive protein value of the Hybrid African catfish fed graded levels of dietary $P$ at the end of 42 days ${ }^{1}$.

\begin{tabular}{|c|c|c|c|c|c|}
\hline \multirow[b]{2}{*}{ Growth parameter } & \multicolumn{5}{|c|}{ Diet, Supplemented phosphorus level in diet (\%) } \\
\hline & $\begin{array}{l}\mathrm{D}_{1} \\
0.60\end{array}$ & $\begin{array}{l}\mathrm{D}_{2} \\
0.80\end{array}$ & $\begin{array}{l}\mathrm{D}_{3} \\
1.00\end{array}$ & $\begin{array}{l}\mathrm{D}_{4} \\
1.20\end{array}$ & $\begin{array}{l}\mathrm{D}_{5} \text { (Control), } \\
0.00\end{array}$ \\
\hline Feed intake $(\mathrm{FFW})(\mathrm{g})$ & $\begin{array}{l}1.46 \\
\pm 0.44 \mathrm{a}\end{array}$ & $\begin{array}{l}1.57 \\
\pm 0.50 \mathrm{a}\end{array}$ & $\begin{array}{l}1.12 \\
\pm 0.22 \mathrm{a}\end{array}$ & $\begin{array}{l}1.84 \\
\pm 0.47 \mathrm{a}\end{array}$ & $\begin{array}{l}1.67 \\
\pm 0.52 \mathrm{a}\end{array}$ \\
\hline $\begin{array}{l}\text { Feed conversion ratio } \\
(\mathrm{FCR})^{2}\end{array}$ & $\begin{array}{l}30.79 \\
\pm \quad 23.03 \\
\mathrm{a}\end{array}$ & $\begin{array}{l}28.76 \\
\pm 26.52 \mathrm{a}\end{array}$ & $\begin{array}{l}-3.26 \\
\pm 3.31 \mathrm{a}\end{array}$ & $\begin{array}{l}0.01 \\
\pm \quad 28.32 \\
\mathrm{a}\end{array}$ & $\begin{array}{l}0.63 \\
\pm 34.42 \mathrm{a}\end{array}$ \\
\hline Protein intake $(\mathrm{PI})(\mathrm{g})^{3}$ & $\begin{array}{l}0.037 \\
\pm \quad 0.011 \\
\mathrm{a}\end{array}$ & $\begin{array}{l}0.041 \\
\pm 0.013 \mathrm{a}\end{array}$ & $\begin{array}{l}0.03 \\
\pm 0.06 \mathrm{a}\end{array}$ & $\begin{array}{l}0.049 \\
\pm 0.01 \mathrm{a}\end{array}$ & $\begin{array}{l}0.051 \\
\pm 0.01 \mathrm{a}\end{array}$ \\
\hline $\begin{array}{l}\text { Productive protein value } \\
(\mathrm{PPV})^{4}\end{array}$ & $\begin{array}{l}0.006 \\
\pm 0.07 \mathrm{a}\end{array}$ & $\begin{array}{l}0.006 \\
\pm 0.01 \mathrm{a}\end{array}$ & $\begin{array}{l}0.008 \\
\pm 0.1 \mathrm{a}\end{array}$ & $\begin{array}{l}0.005 \\
\pm 0.02 \mathrm{a}\end{array}$ & $\begin{array}{l}0.008 \\
\pm 0.67 \mathrm{a}\end{array}$ \\
\hline
\end{tabular}

${ }^{1}$ Values followed by the same letters are not significantly different $(\mathrm{P}>0.05)$.

${ }^{2}$ Feed conversion ratio $(\mathrm{FCR})=\frac{\text { feed intake }}{\text { mean weight gain }}$.

${ }^{3}$ Protein intake $(\mathrm{PI})=\frac{\text { feed intake }}{\text { percentage protein in the diet }}$.

${ }^{4}$ Productive protein value $(\mathrm{PPV})=\frac{\text { increment of body protein }(\%)}{\text { protein intake }(\%)}$, a ratio of retained body protein-to-protein intake.

Table 5: Mean feed conversion ratio (FCR) ${ }^{1}$ of the Hybrid African catfish (Clarias gariepinus $x$ Heterobranchus bidorsalis) fed graded levels of dietary phosphorus for 42 days ${ }^{2}$.

\begin{tabular}{llllll}
\hline \multirow{2}{*}{$\begin{array}{l}\text { Period } \\
\text { days })\end{array}$} & \multicolumn{5}{l}{ Diet, Supplemented phosphorus (P) levels in diet (\%) } \\
\cline { 2 - 6 } & $\mathrm{D}_{1}$, & $\mathrm{D}_{2}$, & $\mathrm{D}_{3}$, & $\mathrm{D}_{4}$, & $\mathrm{D}_{5}$ (Control), \\
\hline 7 & 0.60 & 0.80 & 1.00 & 1.20 & 0.00 \\
14 & 3.85 & 1.83 & 1.62 & 2.21 & 1.28 \\
21 & 0.95 & 1.06 & 1.17 & 0.67 & 1.16 \\
28 & 28.25 & 22.00 & 29.20 & 31.00 & 24.33 \\
35 & 126.00 & -43.33 & -29.25 & 179.00 & -28.00 \\
42 & -35.33 & -121.00 & -52.50 & 0.01 & 199.00 \\
\hline
\end{tabular}

${ }^{1}$ Feed conversion ratio $=$ Feed intake/weight gain.

${ }^{2}$ Values are means of 3 determinations; means in a row followed the same letters are not significantly different $(\mathrm{P}>0.05)$. 